\title{
Implications of agricultural management on the epigeic fauna and soil physical properties of a clayey Oxisol
}

\author{
Lidiane Martins da Costa ${ }^{1 *}$, Marta Sandra Drescher ${ }^{2}$
}

$10.1590 / 0034-737 X 201865050009$

\begin{abstract}
The intensive use of land based on non-conservation practices contributes to the reduction of soil quality. In this sense, the objective of this work was to evaluate the influence of farming systems on clayey Oxisol in the northwest of the state of Rio Grande do Sul on the epigeic fauna and on the soil physical properties. The treatments were composed of land use with Native field, Pasture, Transition, Crop and livestock integration, No-tillage and No-tillage system. The epigeic fauna was evaluated by the installation of seven traps per treatment. The physical properties of density, total porosity, microporosity, macroporosity and soil resistance to penetration were evaluated in samples with undisturbed structure at the $0-0.07,0.07-0.15$ and $0.15-0.22 \mathrm{~m}$ depths, with four replicates. The results indicated that land use only for crop production reduced the abundance of organisms in comparison to the crop-livestock integration. The conversion of the Pampa Biome to the crop system altered its soil physical and biological properties with the transition area presenting intermediate characteristics to both environments. Grazing in the remaining areas of the Pampa Biome, without native field improvement strategies, reduced species abundance and richness. No-tillage and No-tillage system promoted the compaction of the $0.07-0.15 \mathrm{~m}$ layer in a clayey Oxisol.
\end{abstract}

Keywords: anthropic perturbations; soil quality; sustainability.

\section{RESUMO}

\section{Implicações do manejo agropecuário sobre a fauna epigeica e propriedades físicas de um Latossolo argiloso}

O uso intensivo da terra alicerçado em práticas não conservacionistas, tem contribuído para a redução da qualidade do solo. Nesse sentido, o trabalho objetiva avaliar a influência de sistemas de produção agropecuária praticados em Latossolo argiloso no noroeste do estado do Rio Grande do Sul sobre a fauna epigeica e propriedades físicas do solo. Os tratamentos foram compostos pelo uso do solo com campo nativo, pastagem perene, transição, sistema integração lavoura pecuária, plantio direto e sistema plantio direto. A fauna epigeica foi avaliada pela instalação de sete armadilhas por tratamento. As propriedades físicas de densidade, porosidade total, microporosidade, macroporosidade e resistência do solo a penetração, foram avaliadas em amostras com estrutura indeformada nas profundidades de 0- 0.07, 0.07-0.15 e 0,15 a $0,22 \mathrm{~m}$, com quatro repetições. Os resultados obtidos indicaram que o uso do solo apenas agrícola reduziu à abundância de organismos em comparação a integração lavoura-pecuária. A conversão do Bioma Pampa para lavoura alterou as propriedades físicas e biológicas do solo, com a área de transição apresentando características intermediárias aos dois ambientes. O pastejo em áreas remanescentes do Bioma Pampa, sem estratégias de melhoramento do campo nativo, diminuiu a abundância e riqueza de espécies. O Plantio Direto e Sistema Plantio Direto promoveram a compactação da camada entre 0,07 a $0,15 \mathrm{~m}$ do Latossolo argiloso.

Palavras-chave: perturbações antrópicas; qualidade do solo; sustentabilidade.

Submitted on July $25^{\text {th }}, 2017$ and accepted on August $28^{\text {th }}, 2018$.

'Universidade Estadual do Rio Grande do Sul, São Luiz Gonzaga, Rio grande do Sul, Brazil. costalidiane00@gmail.com; marta-drescher@uergs.edu.br *Corresponding author: costalidiane00@gmail.com 


\section{INTRODUCTION}

The current challenge of Brazilian agriculture is to develop productive systems that ally productivity and environmental sustainability, focusing on the preservation of natural resources and soil quality in these systems (Vezzani \& Mielniczuk, 2009). Soil quality is the capacity to operate within the limits of a natural or managed ecosystem in a way to sustain the productivity, maintain or increase the quality of environment and promote the health of plants, animals and men (Doran \& Parkin, 1994). In this sense, soil quality is a broad concept that refers to the balance between the chemical, physical and biological conditions.

Farming and livestock intensification based on nonconservation agricultural practices contributed to the loss of chemical, physical and biological quality of the soil (Silva et al., 2007), reducing its agricultural potential. The loss of soil physical quality through compaction has been considered as one of the main factors responsible for the drop in the crop productivity (Klein et al., 2009).

The intensification of the compaction process is directly associated with the adopted soil management system (Drescher et al., 2016), combined with the nonconservationist farming practices that induce changes in its structure. The soil mechanical resistance to penetration, together with the porous space distribution, are physical soil attributes that may limit root system growth and crop productivity (Oliveira et al., 2015), since they influence conditions of root growth and aeration, infiltration and water availability for plants (Reichert et al., 2007).

Similar to the physical properties of the soil, the biological properties also represent a component sensitive to the variations of soil management, such as cropping, fertilization, liming and agricultural pesticide applications (Drescher et al., 2011), becoming important bioindicators of balance levels or disturbance of the environment (Ludwig et al., 2012). Management and use systems that enable the addition of organic compounds in the soil may benefit physical quality (Oliveira et al., 2015), since organic matter plays an important role in the formation and stabilization of soil aggregates (Tisdall \& Oades, 1982) besides harboring a diverse population of epiedaphic fauna, which also contributes to the soil structure through the movement of organic particles and nutrient cycling (Pereira et al., 2012).

Apart from the physical characteristics of the soil, the study of the community of soil organisms contributes to a better understanding of the biological interactions in the soil system and, consequently, the determination of the best systems of use and management aiming at improving soil quality.

The diversity of land uses in farming systems is a striking feature of the northwest region of the state of Rio
Grande do Sul (Mantelli, 2006). The region presents soils suitable for the cultivation of annual crops such as soybean (Glycine max L.), maize (Zea mays L.) and wheat (Triticum aestivum L.), in addition to beef and dairy cattle in a grazing system based on integration among livestock farming, perennial pastures and native field (Incra/RS, 2009). However, farming intensification coupled with the valuation of soybean cultivation has resulted in the expansion of agricultural frontiers in recent years, especially in the remaining areas of the Pampa Biome (Silva, 2012), which is the cause of the conversion of native fields into crops.

Hence, the objective of this study was to evaluate the effects of farming systems practiced in a clayey Oxisol in northwestern Rio Grande do Sul on the epigeic fauna and on the physical properties of the soil.

\section{MATERIAL AND METHOD}

The study was carried out in the municipality of São Luiz Gonzaga, located in northwestern Rio Grande do Sul state, between the parallels $28^{\circ} \mathrm{S}$ and $29^{\circ} \mathrm{S}$. The region in this study presents deep, clayey and well drained soils, predominantly of the Oxisols class (Streck et al., 2002). It presents altitudes ranging from 200 to 400 meters, with wavy to gently undulating terrain. The climate is classified as Cfa type, according to the classification of Köppen, subtropical humid, with the four seasons of the year well defined. According to the São Luiz Gonzaga meteorological station, the average annual temperature in the municipality is $16^{\circ} \mathrm{C}$ and the annual rainfall is $1,660 \mathrm{~mm}$ (Incra/RS, 2009). For the accomplishment of this work, six treatments, composed of the main production systems adopted in the region (Incra/RS, 2009), were characterized as follows:

- Native Field (NF): area under extensive grazing system, with no corrections of acidity and soil fertility, representative of the remaining areas of the Pampa Biome in the region;

- Perennial Pasture (PP): area implanted and used with Cynodon dactylon L. Pers (cv. Tifton 85) for dairy cattle grazing approximately seven years ago;

- Transition (TR): area submitted to a native field transition (Pampa Biome) to a grain production system using no-tillage in the last two years;

- Crop and Livestock integrated system (CLIS): cattle raised with oat (Avena strigosa Schreb.) and ryegrass (Lolium multiflorum L.) pasture in the winter, and soybean production under no-tillage in the summer, kept in this system for ten years;

- No-tillage (NT): characterizes the most representative form of farming in the region, the successive monoculture of soybeans and wheat, with no soil tillage for 20 years; 
- No-tillage system (NTS): area cropped in no-tillage system for 20 years and in the last years, the following crop rotation has been carried out: oilseed radish (Raphanus sativus L.)/corn/between harvest (safrinha) soybean; wheat/soybean, wheat/soybean, white oat (Avena sativa L.)/ soybean, oilseed raddish /corn. Crop rotation accomplishment is a factor that distinguishes this treatment from no-till treatment characterized by the successive monoculture of soybean and wheat.

Sampling was carried out in January/2016, in a completely randomized design, with four replications to evaluate the physical properties of the soil and seven replications to evaluate the epigeic fauna.

The analysis of the physical properties of density, total porosity, microporosity and macroporosity of the soil was performed using the volumetric ring and tension table method (Claessen, 1997). For the collection of soil samples with preserved structure, stainless steel cylinders of 141.37 $\mathrm{cm}^{3}$ (5 $\mathrm{cm}$ in height and $6 \mathrm{~cm}$ in diameter) were used. Soil samples were collected at three depths ( 0 to $0.07 ; 0.07$ to 0.15 and, 0.15 to $0.22 \mathrm{~m}$ ), with four replications, totaling 72 samples.

After collection, the samples were saturated by capillarity for a 48-hour period, weighed and taken to the sand column (Reinert \& Reichert, 2006) where they were submitted to a $6 \mathrm{kPa}$-suction tension. The soil samples remained in this tension until a balance was established between the water retained in the sample and the applied suction. The sample was then weighed again, sent to the oven at $105-110{ }^{\circ} \mathrm{C}$, where it remained until obtaining constant weight. Total porosity (Tp), microporosity, macroporosity and soil density (Sd) were determined by the method adopted by Claessen (1997).

Penetration resistance (PR) was evaluated using the bench-type electronic penetrometer, model MA 933 Marconi brand equipped with electronic speed variator and data recording system (Tormena et al., 2007). For determination of the penetration resistance, the same undisturbed samples collected for evaluation of soil density and porosity were used. Thus, after being withdrawn from the sand column, the samples were weighed and, in the sequence, sent to the penetrometer to accomplishment of PR measurement.

For the sampling of the epigeic fauna, seven Providtype traps were installed in each of the six treatments, totaling 42 samples. The Provid type traps consist of $2 \mathrm{~L}-$ PET bottles containing four $5 \times 5 \mathrm{~cm}$ sized windows located $20 \mathrm{~cm}$ from their base (Antoniolli et al., 2006). In each trap, $200 \mathrm{~mL}$ of $70 \%$ ethyl alcohol was added and then the traps were buried, leaving their openings at ground level in order to allow the entrance of edaphic fauna organisms (Drescher et al., 2011). The traps remained in the field for a period of three days.
After the traps were removed from the field, they were sieved in order to separate plant residues from the collected fauna. Subsequently, the samples were separated into plastic glasses with 70\% ethyl alcohol and 5\% glycerol solution lid. The identification and counting of the collected organisms were performed with the help of a binocular magnifying glass with a capacity of 40 times increase in Petri dish. The organisms found were identified at the level of the order according to Gallo et al. (2002).

For the analysis of the physical properties of the soil, the variables were submitted to the test of Lilliefors for normality and of Cochran for homogeneity of variances and, afterwards, the analysis of variance was performed at $5 \%$ probability. When the $\mathrm{F}$ test was significant, the results were compared by the test of Tukey, also at $5 \%$ probability. All the evaluations were carried out in the statistical software Assistat, version 7.7 beta (Universidade Federal de Campina Grande, Campina Grande, PB).

The epigeic fauna was quantitatively evaluated by the abundance of orders and qualitatively by the Simpson Dominance Index (Is), Shannon Diversity Index (H') and Equity Index $(\mathrm{J})$. The Is expresses the probability of individuals within the same community to belong to the same species, being able to vary from 0 to 1 , the higher the value, the greater the dominance of one species over the others. In addition, it is calculated by the equation: Is = $\mathrm{N}(\mathrm{N}-1) / n i(n i-1)$, where: $\mathrm{ni}=$ density of each order; $\mathrm{N}=$ total number of individuals in the group. The $\mathrm{H}$ reflects the uncertainty of randomly catching an individual of the same species, and it ranges from 0 to 5 . The greater the diversity of organisms, the higher the index, which is calculated by the equation: $\mathrm{H}=-\Sigma($ pi $\log$ pi), where: $\mathrm{pi}=\mathrm{ni} / \mathrm{N}$; $\mathrm{ni}=$ density of each order; $\mathrm{N}=$ total number of individuals in the group (Silva et al., 2015). Equity or Pielou index (J) expresses the way in which the number of individuals is distributed among the different species, that is, it indicates if the different species have similar or divergent abundance (number of individuals), calculating as follows: $\mathrm{J}^{\prime}=\mathrm{H}^{\prime}$ (observed)/H'maximum, where: H'max is the maximum possible diversity that can be observed if all species are equally abundant. H'maximum $=\log \mathrm{S}$, where: $\mathrm{S}=$ total number of species (Gomes \& Ferreira, 2004).

\section{RESULTS AND DISCUSSION}

Fifteen taxanomic groups (order level) at an abundance of 5,633 individuals were found in the epigeic fauna study. The orders Hymenoptera, Coleoptera and Collembola were the most representative in the soil of the studied systems. The TR treatment showed the highest abundance of collected organisms (Table 1), followed by PP, NF, CLIS, NT and, finally, by NTS. The continuous use of the soil only for grain production did not favor the abundance of 
organisms, since NT and NTS presented a lower abundance by 41 and $59 \%$ respectively, than TR, used for grain production only in the last two years, indicating that the intensity of land use is a determining factor for the biodiversity and abundance of terrestrial fauna, as also observed by Rosa et al. (2015).

The TR treatment also presented a greater diversity of the epigeic fauna population determined by the $\mathrm{H}^{\prime}$ index and a greater equitability, that is, the number of individuals is better distributed in relation to the others. Index H' considers the richness, so it is natural that the treatments that obtained the greatest richness of species, present a greater value. The treatments TR, PP and CLIS presented a greater number of organisms with a total of thirteen orders, followed by NTS (twelve orders), NT (eleven orders) and by NF with nine orders.

The NTS had smaller abundance, diversity and equitability of the epigeic fauna (Table 1 ). This result may represent the influence of farming practices with the application of chemicals on soil fauna (Baretta et $a l ., 2003)$, considering that it is an environment with a greater number of annual crops. In addition, the soil evaluation period was preceded by the cultivation of soybean and oilseed raddish, whose cultural residues present low soil permanence (Doneda et al., 2012), which may have conditioned a low availability of organic ma- terial for the maintenance of edaphic fauna. The PP and NF presented a greater abundance of the order Hymenoptera, indicating quality of these environments, as indicated by Crepaldi et al. (2014) who consider this order of fundamental importance for soil quality maintenance, being useful as a bioindicator of this condition. According to Vieira et al. (2011) the structure of the Hymenoptera communities is fundamental in environmental impact studies, since they maintain and restore soil quality, operating in the redistribution of particles, nutrients and organic matter, improve the infiltration of water in the soil by increasing aeration through increased porosity (Wink et al., 2005). The NTS presented lower abundance of Hymenoptera, indicating a disturbance to the ecological balance (Rovedder et al., 2009; Baretta, 2007; Baretta et al., 2003).

The order Collembola presented the greatest abundance in the CLIS, TR, NF and PP treatments with reduction for the treatments NT and NTS, which may be an indicative of perturbations in these environments. This result is shown to be relevant, as springtails are important in the process of formation, dynamics and evolution of soils, being more frequently found in environments rich in organic matter, acting on nutrient cycling and decomposition of organic matter of plant origin (Rocha, 2013).

Table 1: Epidafic fauna diversity of the major taxonomic orders found in land use systems in the municipality of São Luiz Gonzaga-RS

\begin{tabular}{|c|c|c|c|c|c|c|c|}
\hline \multirow{2}{*}{ Taxonomic orders } & \multicolumn{7}{|c|}{ Land Use System } \\
\hline & $\mathbf{N F}$ & $\mathbf{P P}$ & TR & CLIS & NT & NTS & Total in the order \\
\hline Hymenoptera & 457 & 717 & 184 & 168 & 251 & 103 & 1880 \\
\hline Coleoptera & 61 & 185 & 391 & 115 & 256 & 183 & 1191 \\
\hline Collembola & 203 & 152 & 233 & 335 & 71 & 129 & 1123 \\
\hline Orthoptera & 19 & 36 & 173 & 12 & 144 & 38 & 422 \\
\hline Acarine & 22 & 59 & 93 & 161 & 7 & 41 & 383 \\
\hline Diptera & 47 & 62 & 154 & 19 & 38 & 23 & 343 \\
\hline Araneae & 18 & 16 & 72 & 5 & 14 & 17 & 142 \\
\hline Hemiptera & 12 & 51 & 17 & 2 & 4 & 9 & 95 \\
\hline Thysanoptera & 5 & 21 & 1 & 1 & 2 & 3 & 33 \\
\hline Lepidoptera & 0 & 1 & 4 & 2 & 2 & 1 & 10 \\
\hline Dermaptera & 0 & 0 & 3 & 0 & 0 & 1 & 4 \\
\hline Blattodea & 0 & 1 & 1 & 0 & 0 & 0 & 2 \\
\hline Isoptera & 0 & 1 & 0 & 1 & 0 & 0 & 2 \\
\hline Scorpionidae & 0 & 0 & 0 & 0 & 2 & 0 & 2 \\
\hline Isopoda & 0 & 0 & 0 & 1 & 0 & 0 & 1 \\
\hline Larva & 0 & 10 & 5 & 14 & 0 & 4 & 33 \\
\hline Abundance & 844 & 1302 & 1326 & 822 & 791 & 548 & \\
\hline $\mathrm{S}$ (richness) & 9 & 13 & 13 & 13 & 11 & 12 & \\
\hline H’ (Shannon's richness) & 1.17 & 1.54 & 1.93 & 1.29 & 1.26 & 1.12 & \\
\hline Is (Simpson's dominance) & 0.15 & 0.34 & 0.18 & 0.10 & 0.09 & 0.04 & \\
\hline J (Pielou's equitability) & 0.53 & 0.60 & 0.75 & 0.50 & 0.53 & 0.45 & \\
\hline
\end{tabular}

NF: native field; PP: pasture; TR: transition; CLIS=: crop livestock integration system; NT: no-tillage; NTS: no-tillage system

Rev. Ceres, Viçosa, v. 65, n.5, p. 443-449, set/out, 2018 
The Coleoptera order was present in all treatments, presenting fluctuations in its population, which can be attributed to the ability of each species to explore specific trophic niches (Table 1) (Rosa et al., 2015). The greatest abundance of this order was observed in the TR treatment, which according to Baretta (2007) is an indicative of anthropogenic disturbances to a natural environment, through the use of fertilizers $(\mathrm{N}, \mathrm{P}, \mathrm{K})$ and pesticides, being consistent with the reality of this treatment, as it is a transition from a natural environment to a grain production system.

Despite being representative of the natural ecosystem, NF presented lower species richness, which may be due to the presence of grazing, which acts selectively on field species, altering the biomass content as well as the low nutritional quality of the area since it does not receive correctives and fertilizers. The richness of edaphic fauna is related to the availability and quality of plant cover as a source of nutrients and shelter (Rovedder et al., 2009). Thus, practices such as NF improvement through fertilization and introduction of forage species over seeding or direct seeding, by contributing to a larger forage production, especially in winter and early spring, may contribute to the addition of organic compounds to the soil and increase the potential to shelter a diverse population of epidafic fauna. Another important aspect that may contribute to the balance of the epidafic fauna is the adjustment of the animal load per hectare as a function of the existing forage supply in the area.

Regarding the soil structure, indicated by the physical properties of $\mathrm{Sd}$, porosity and $\mathrm{PR}$, it was observed that in the 0-0.07 m layer, the assessed treatments did not differ in any of the physical attributes evaluated (Table 2). However, although no differences were observed between the treatments, when observing the penetration resistance in the 0-0.07 m layer, it is possible to verify that the NF exceeded the value of 2.0 MPa, often considered as restrictive to root growth of the cultures (Reichert et al., 2009; Collares et al., 2006). This result can be attributed to animal trampling, which results in the formation of superficial layers with greater resistance (Kunz et al., 2013), especially under conditions of high grazing pressure, which in the present study may be attributable to the absence of breeding practices on the NF submitted to cattle grazing.

At the 0.07-0.15 $\mathrm{m}$ depth, the treatments CLIS, NT, NTS and TR used for grain production showed a greater density. This behavior can be explained by the accumulation of tensions imposed by the traffic of farming machines. In addition, this layer is recognized as the most restrictive layer to the root growth of the plants in areas managed under NTS as it was also observed by Secco et al., (2009) and Drescher et al. (2016). In this sense, it should be highlighted that considering the critical density proposition of 1.30 to $1.40 \mathrm{Mg} \mathrm{m}^{-3}$ for clayey soils (Reichert et al., 2003), the treatments that contemplate the grain production of CLIS, NTS and NT would be in a restrictive range, and could be considered critical to the development of crops. The TR treatment presents soil density with both NF and crop characteristics, making it possible to observe that after two years of management, the TR is in transition phase between the two production systems.

In the 0.07-0.15 m layer, a greater resistance to root penetration was observed in the NT, surpassing 2.0 MPa, a value often considered critical for the root growth of the cultures (Reichert et al. 2009; Collares et al. 2006). This behavior can be attributed to the absence of crop rotation in this productive system, which, combined with the continuous traffic of machines, contributes to the formation of soil layers resistant to root penetration (Secco et al., 2009).

The no-tillage system unveiled lower Tp in the 0.07$0.15 \mathrm{~m}$ layer, consistent with the greater $\mathrm{Sd}$. Thus, it is possible to observe a degradation of the soil structure, indicating in the NTS, a tendency for compaction in the subsurface layer in areas with crop rotation of low organic matter intake such as soybeans and oilseed radish, crops with low straw permanence that preceded the moment of evaluation of the soil physical properties. This result is in contrast to that observed by Williams \& Weil (2004), that roots of oilseed radish act as recovering agents of the physical properties of the soil through the formed biopores, which benefit the development of the root system of subsequent crops. However, it should be emphasized that the susceptibility of a soil to compaction becomes smaller as the amount of plant residue in the soil surface is increased (Braida et al., 2006), and the permanence of this straw is very important for the accumulation of carbon at the soil surface. Thus, the use of oilseed raddish in single crop may result in a rapid decomposition and low permanence of the straw, since the biomass is easily and rapidly decomposed due to the low carbon/nitrogen $(\mathrm{C} / \mathrm{N})$ ratio. For that reason, oilseed raddish intercropped with crops such as oats is recommended since it allows greater coverage and permanence of the straw on the soil (Silva et al., 2011).

In the 0.15-0.22 m layer, treatments differed to the $\mathrm{Sd}$, PR and macroporosity of the soil. The NF presented the smallest PR and the greatest macroporosity. This result allows to observe that the management systems used for grain production cause alterations in the physical properties of the soil reaching the subsurface layers up to $0.22 \mathrm{~m}$ depth. 
Table 2: Soil density (Sd), total porosity (Tp), soil macroporosity (Macrop.), soil microporosity (Microp.) and penetration resistance (PR) in productive systems managed under native field (NF), crop livestock integrations (CLIS), Pasture (PP), no-tillage (NT), no-tillage system (NTS) and transition (TR)

\begin{tabular}{|c|c|c|c|c|c|}
\hline \multirow{3}{*}{ Treatments } & \multicolumn{5}{|c|}{ Parameters } \\
\hline & Sd & $\mathbf{T p}$ & Macrop. & Microp. & PR \\
\hline & $\mathrm{Mg} \mathrm{m}^{-3}$ & \multicolumn{3}{|c|}{$\mathbf{m}^{3} \mathbf{m}^{-3}$} & Mpa \\
\hline \multicolumn{6}{|c|}{$0-0.07 \mathrm{~m}$ depth } \\
\hline $\mathrm{NF}$ & $1.17^{\mathrm{ns}}$ & $0.56^{\mathrm{ns}}$ & $0.08^{\text {ns }}$ & $0.48^{\mathrm{ns}}$ & $2.22 \mathrm{~ns}$ \\
\hline CLIS & 1.32 & 0.53 & 0.10 & 0.43 & 1.52 \\
\hline PP & 1.18 & 0.57 & 0.09 & 0.49 & 1.83 \\
\hline NT & 1.25 & 0.57 & 0.13 & 0.44 & 1.88 \\
\hline NTS & 1.27 & 0.54 & 0.11 & 0.44 & 1.62 \\
\hline $\mathrm{TR}$ & 1.24 & 0.55 & 0.10 & 0.45 & 1.56 \\
\hline$\overline{\mathrm{CV}(\%)}$ & 9.37 & 7.01 & 55.06 & 5.8 & 20.35 \\
\hline \multicolumn{6}{|c|}{$0.07-0.15 \mathrm{~m}$ depth } \\
\hline NF & $1.16 \mathrm{c}$ & $0.55 \mathrm{a}$ & $0.14 \mathrm{a}$ & $0.41^{\mathrm{ns}}$ & $1.35 \mathrm{ab}$ \\
\hline CLIS & $1.44 \mathrm{a}$ & $0.52 \mathrm{ab}$ & $0.08 \mathrm{ab}$ & 0.44 & $1.58 \mathrm{ab}$ \\
\hline NP & $1.23 \mathrm{bc}$ & $0.56 \mathrm{a}$ & $0.13 \mathrm{ab}$ & 0.43 & $1.26 \mathrm{~b}$ \\
\hline NT & $1.38 \mathrm{ab}$ & $0.52 \mathrm{ab}$ & $0.07 \mathrm{~b}$ & 0.46 & $2.03 \mathrm{a}$ \\
\hline NTS & $1.40 \mathrm{ab}$ & $0.49 \mathrm{~b}$ & $0.06 \mathrm{~b}$ & 0.42 & $1.64 \mathrm{ab}$ \\
\hline $\mathrm{TR}$ & $1.27 \mathrm{abc}$ & $0.54 \mathrm{ab}$ & $0.08 \mathrm{ab}$ & 0.46 & $1.31 \mathrm{ab}$ \\
\hline $\mathrm{CV}(\%)$ & 6.3 & 5.18 & 33.37 & 5.4 & 22.13 \\
\hline \multicolumn{6}{|c|}{$0.15-0.22 \mathrm{~m}$ depth } \\
\hline $\mathrm{NF}$ & $1.09 \mathrm{~b}$ & $0.56^{\text {ns }}$ & $0.17 \mathrm{a}$ & 0.39 ns & $0.62 \mathrm{~b}$ \\
\hline CLIS & $1.30 \mathrm{ab}$ & 0.53 & $0.08 \mathrm{ab}$ & 0.44 & $1.57 \mathrm{a}$ \\
\hline PP & $1.22 \mathrm{ab}$ & 0.56 & $0.12 \mathrm{ab}$ & 0.44 & $1.25 \mathrm{a}$ \\
\hline NT & $1.27 \mathrm{ab}$ & 0.56 & $0.12 \mathrm{ab}$ & 0.45 & $1.22 \mathrm{a}$ \\
\hline NTS & $1.42 \mathrm{a}$ & 0.47 & $0.09 \mathrm{ab}$ & 0.39 & $1.35 \mathrm{a}$ \\
\hline $\mathrm{TR}$ & $1.24 \mathrm{ab}$ & 0.52 & $0.07 \mathrm{~b}$ & 0.45 & $1.49 \mathrm{a}$ \\
\hline$\overline{\mathrm{CV}(\%)}$ & 7.96 & 9.69 & 38.55 & 12.51 & 15.57 \\
\hline
\end{tabular}

${ }^{\mathrm{n} s}$ Means in the column are not statistically different by the test of Tuckey at the level of $5 \%$ of probability.

\section{CONCLUSIONS}

The edaphic fauna is influenced by the productive system, and land use only for grain production impairs the abundance of organisms in comparison to the systems that associate crop and livestock.

The use of remaining areas of the Pampa Biome for grazing, not in association with native field improvement strategies, promotes changes in edaphic fauna, resulting in a decrease in the abundance of organisms and species richness.

The changing process in land use promotes modifications on the physical and biological characteristics of the soil, where after two years of management, the transition area between natural environment and productive system, presents intermediate characteristics to both environments.

The successive single cultivation of soybean and wheat and crop rotation with cultures of low permanence of straw promote the compaction of the layer between 0.07 and $0.15 \mathrm{~m}$ of the clayey Oxisol managed under no-tillage.

\section{ACKNOLWDEGMENTS}

To farmers Mr. Nelmo Costa, Mr. Paulo Pires, Mr. Valdir Moraes and Mr. Marcos Pilecco for granting the areas for accomplishment of this work.

\section{REFERENCES}

Antoniolli ZI, Conceição PC, Bock V, Port O, Silva DM \& Silva RF (2006) Método alternativo para estudar a fauna do solo. Ciência Florestal, 16:407-417.

Baretta D (2007) Fauna do solo e outros atributos edáficos como indicadores da qualidade ambiental em áreas com Araucária angustifólia no Estado de São Paulo. Tese de Doutorado. Escola Superior de Agricultura "Luiz de Queiroz", São Paulo. 158p.

Baretta D, Santos JCP, Mafra AL, Wildner LP \& Miquelluti DJ (2003) Fauna edáfica avaliada por armadilhas e catação manual afetada pelo manejo do solo na região oeste catarinense. Revista de Ciências Agroveterinária, 2:97-106.

Braida JA, Reichert JM, Veiga M \& Reinert DJ (2006) Resíduos vegetais na superfície e carbono orgânico do solo e suas relações com a densidade máxima obtida no ensaio proctor. Revista Brasileira de Ciência do Solo, 30:605-614. 
Claessen MEC (1997) Manual de métodos de análise de solo. $2^{\mathrm{a}}$ ed. Rio de Janeiro, Embrapa CNPS. 212p.

Collares GL, Reinert DJ, Reichert JM \& Kaiser DR (2006) Qualidade física do solo na produtividade da cultura do feijoeiro num Argissolo. Pesquisa Agropecuária Brasileira, 41:1663-1674.

Crepaldi RA, Portilho IIR, Silvestre R \& Mercante FM (2014) Formigas como bioindicadores da qualidade do solo em sistema integrado lavoura-pecuária. Ciência Rural, 44:781-787.

Doneda A, Aita C, Giacomini SJ, Miola ECC, Giacomini DA, Schirmann J \& Gonzatto R (2012) Fitomassa e decomposição de resíduos de plantas de cobertura puras e consorciadas. Revista Brasileira de Ciência do Solo, 36:1714-1723.

Doran JW \& Parkin TB (1994) Defining and assessing soil quality. In: Doran JW, Coleman DC, Bezdicek DF \& Stewart BA (Eds.) Defining Soil Quality for a Sustainable Environment. Madison, Soil Science Society of America. p.03-21.

Drescher MS, Reinert DJ, Denardin JE, Gubiani PI, Faganello A \& Drescher GL (2016) Duração das alterações em propriedades fisico hidricas de Latossolo argiloso decorrentes da escarificação mecânica. Pesquisa Agropecuária Brasileira, 51:159-168.

Drescher MS, Rovedder APM, Antoniolli ZI, Eltz FLF \& Drescher GL (2011) Fauna epigeica em sistemas de produção de Nicotiana tabacum L. Revista Brasileira de Ciência do Solo, 35:14991507.

Gallo D, Nakano O, Silveira Neto S, Carvalho RPL, Batista GC, Berti Filho E, Parra JRP, Zucchi RA, Alves SB, Vendramim JD, Marchini LC, Lopes JRS \& Omoto C (2002) Entomologia Agrícola. São Paulo, FEALQ. 920p.

Gomes AS \& Ferreira SP (2004) Análise de Dados Ecológicos. Niterói, Universidade Federal Fluminense. 30p.

INCRA/RS - Instituto Nacional de Colonização e Reforma Agrária (2009) Relatório ambiental do projeto de assentamento panorama São Luiz Gonzaga/RS. Porto Alegre, INCRA. 115p.

Klein VA, Baseggio M \& Madalosso T (2009) Indicadores da qualidade física de um Latossolo Vermelho distrófico típico sob plantio direto escarificado. Ciência Rural, 39:2475 2481.

Kunz M, Gonçalves ADMA, Reichert JM, Guimarães RML, Reinert DJ \& Rodrigues MF (2013) Compactação do solo na integração soja-pecuária de leite em Latossolo argiloso com semeadura direta e escarificação. Revista Brasileira de Ciência do Solo, 37:1699-1708

Ludwig RL, Pizzani R, Schaefer PE, Goulart RZ \& Lovato T (2012) Efeito de diferentes sistemas de uso do solo na diversidade da fauna edáfica na região central do Rio Grande do Sul. Enciclopédia Biosfera, 8:485-495.

Mantelli J (2006) O setor agrário da região noroeste do Rio Grande do Sul. Geosul, 21:87-105.

Oliveira DMS, Lima RP \& Verburg EEJ (2015) Qualidade física do solo sob diferentes sistemas de manejo e aplicação de dejeto líquido suíno. Revista Brasileira de Engenharia Agrícola e Ambiental, 19:280-285.

Pereira RC, Albanez JM \& Mamédio IMP (2012) Diversidade da meso e macrofauna edáfica em diferentes sistemas de manejo de uso do solo em Cruz das Almas - BA, Magistra, 24:63-76.

Reichert JM, Suzuki LEAS \& Reinert DJ (2007) Compactação do solo em sistemas agropecuários e florestais: identificação, efeitos, limites críticos e mitigação. Tópicos Ciência do Solo, 5:49134

Reichert JM, Kaiser DR, Reinert DJ \& Riquelme UFB (2009) Variação temporal de propriedades físicas do solo e crescimento radicular de feijoeiro em quatro sistemas de manejo. Pesquisa Agropecuária Brasileira, 44:310-319.
Reichert JM, Reinert DJ \& Braida JA (2003) Qualidade dos solos e sustentabilidade de sistemas agrícolas. Ciência Ambiental, 27:2948 .

Reinert DJ \& Reichert JM (2006) Coluna de areia para medir a retenção de água no solo - protótipos e teste. Ciência Rural, 36:1931 1935.

Rocha IMS (2013) Colembola (Arthropoda: Hexapoda: Collembola) numa área de caatinga do nordeste brasileiro. Dissertação de Mestrado. Universidade Federal do Rio Grande do Norte, Natal. 56p.

Rosa MG, Filho OK, Bartz MLC, Mafra ÁL, Souza JPFA \& Baretta D (2015) Macrofauna Edáfica e Atributos Físicos Químicos em Sistemas de Uso do Solo no Planalto Catarinense. Revista Brasileira de Ciência do Solo, 39:1544-1553.

Rovedder APM, Eltz FLF, Drescher MS, Schenato RB \& Antoniolli ZI (2009) Organismos edáficos como bioindicadores da recuperação de solos degradados por arenização no Bioma Pampa. Ciência Rural, 39:1061-1068.

Secco D, Reinert DJ, Reichert JM \& Silva VR (2009) Atributos físicos e rendimento de grãos de trigo, soja e milho em dois Latossolos compactados e escarificados. Ciência Rural, 39:5864.

Silva DA da, Souza LCF de, Vitorino ACT \& Gonçalves MC (2011) Aporte de fitomassa pelas sucessões de culturas e sua influência em atributos físicos do solo no sistema plantio direto. Bragantia, 70:147-156.

Silva MB, Kliemann HJ, Silveira PM \& Lanna AC (2007) Atributos biológicos do solo sob influência da cobertura vegetal e do sistema de manejo. Pesquisa Agropecuária Brasileira, 42:17551761 .

Silva MDDA (2012) Os cultivos florestais do pampa, no sul do rio grande do sul: desafios, perdas e perspectivas frente ao avanço de novas fronteiras agrícolas. Floresta, 42:215-226.

Silva DAA, Silva D, Jaques RJS \& Antoniolli ZI (2015) Bioindicadores de qualidade edáfica em diferentes usos do solo. Enciclopédia Biosfera, 22:3728-3736.

Streck EV, Kampf N, Dalmolin RSD, Klamt E, Nascimento PCN \& Schneider P (2002) Solos do Rio Grande do Sul. Porto Alegre, EMATER/RS. 107p.

Tisdall JM \& Oades JM (1982) Organic matter and water-stable aggregates in soils. Journal of Soil Science, 33:141-163.

Tormena CA, Araújo MA, Fidalski J \& Costa JM (2007) Variação temporal do intervalo hídrico ótimo de um Latossolo Vermelho distroférrico sob sistemas de plantio direto. Revista Brasileira de Ciência do Solo, 31:211-219.

Vezzani FM \& Mielniczuk J (2009) Uma visão sobre qualidade do solo. Revista Brasileira de Ciência do Solo, 33:743-755.

Vieira NYC, Vidotto FL, Cardoso JA, Silva CV \& Schneider LCL (2011) Diversidade de insetos bioindicadores em área de cultivo de milho transgênico no município de Arapongas, PR. In: VII EPCC - Encontro Internacional de Produção Científica Cesumar, Maringá. Anais, CESUMAR. p. 01-04.

Wink C, Guedes JVC, Fagundes CK \& Rovedder AP (2005) Insetos edáficos como indicadores da qualidade ambiental. Revista de Ciências Agroveternárias, 4:60-71.

Williams SM \& Weil RR (2004) Crop cover root channels may alleviate soil compaction effects on soybean crop. Soil Science Society of America Journal, 68:1403-1409.

Rev. Ceres, Viçosa, v. 65, n.5, p. 443-449, set/out, 2018 